\title{
Voltammetric Determination of Catalytic Effect of Nitrite in Nitrate Media by Graphite and Mercury Electrode on Acid Red-27 Cobalt Complex
}

\author{
Okan UÇARLI*' \\ Department of Medical Imagining Techniques Program, Espiye Vocational School, Giresun University, \\ Giresun 28600, Turkey
}

Geliş / Received: 30/10/2020, Kabul / Accepted: 12/12/2020

\begin{abstract}
In this study, the catalytic effect of nitrite on the cobalt complex of acid red 27, which is one of the most important azo dyes today, was investigated. Voltammetric studies were carried out with a Hanging mercury drop electrode (HMDE) and pencil graphite electrode (PGE) using the Cathodic Adsorptive Square Wave Voltammetry (CAdsSWV) technique in nitrate media. First, in situ formation of the complex was determined by electrochemical method. It was then observed that the voltammetric peak current of the complex increased in the presence of nitrite anions. The deposition time, potential and nitrite concentration were investigated to optimize the conditions for both electrodes. According to the results, the reaction mechanism of the catalytic effect of nitrite has been proposed.
\end{abstract}

Keywords: Mercury Electrode, Graphite Electrode, Adsorptive Voltammetry, Catalytic Effect, Azo Dye

\section{Nitrat ortamında Nitritin Katalitik Etkisinin Asit Kırmızısı-27 Kobalt Kompleksi Üzerine Grafit ve} Cıva Elektrot ile Voltammetrik Araştırılması

\section{$\ddot{O} \mathbf{z}$}

Bu çalışmada günümüzde çok önemli azo boyar maddelerden biri olan asit kırmızısı 27'nin kobalt kompleksi üzerine nitritin katalitik etkisi nitrat ortamında incelenmiştir. Voltammetrik çalışmalar asılı cıva damla elektrodu ve kalem grafit elektrot (KGE) ile Katodik Adsorptif Kare Dalga Voltammetri (KAdsKDV) tekniğiyle gerçekleştirilmiştir. Öncelikle asit kırmızısı 27 ile kobalt iyonu kompleksi oluşumu elektrokimyasal metod ile belirlenmiştir. Bundan sonra kompleksin voltammetrik pik akımının nitrit anyonlarının varlığında arttığ 1 gözlenmiştir. Her iki elektrotta koşulların optimize edilmesi için biriktirme süresi, potansiyeli ve nitrit konsantrasyonu araştırılmıştır. Elde edilen sonuçlara göre nitritin katalitik etkisinin reaksiyon mekanizması her iki elektrot için önerilmiştir.

Anahtar Kelimeler: Civa Elektrot, Grafit Elektrot, Adsorptif Voltammetri, Katalitik Etki, Azo Boyarmadde

\section{Introduction}

Functional groups in aliphatic and aromatic structures that contain an azo $-\mathrm{N}=\mathrm{N}$ - group and give color to the molecule are called Azo compounds. Azo dyes usually consist of conjugated systems that combine two or more aromatic rings in their structure. The compounds containing azo groups are called "azo dyes" to distinguish them from other dyes. They are also called monoazo, diazo, and triazo compounds depending on the number of Azo groups they contain (Murty et al., 2012). 
Azo dyestuffs are used in many areas such as dye chemistry, medicinal chemistry, textile chemistry, trace element analysis, industrial wastes, food chemistry, biological studies, carcinogenetic properties and metabolic studies, because they have been deemed worthy of research (Patai, 1975; Griffith, 1976; Strandis and Glezer, 1979; Hart and Smyth, 1980). Because of these properties, it is important to determine and quantify azo dyes.

Acid red 27 (AR-27) is dark red and purple azo dye in Figure1. It was early used in food in the United States, as a dyestuff and dye in cosmetics, but since 1976 it has been banned in the United States by the Food and Drug Administration (FDA) on charges of carcinogenesis. Voltammetry is of great importance in studies on azo dyes and their metal complexes (Karaman et al., 2018; Karaman et al., 2015; Karaman and Menek 2012; Menek et al., 2013; Menek et al., 2006a; Menek and Karaman 2005; Menek and Topçu, 2003; Menek et al., 2001). Voltammetric studies with carbon electrodes have recently been intensified since voltammetry is a fast and accurate technique (Karaman, 2014).

In recent years, modern electrochemical techniques, especially square wave voltammetry (SWV) which improve sensitivity and selectivity have promoted the development of many electrochemical methods for ultra- trace measurements of a variety of organic and inorganic compounds. The popularities of adsorptive stripping voltammetry (AdsV) and catalytic adsorptive stripping voltammetry (CatAdsV) have been steadily increasing in the determination of ultra trace concentrations of metals. This is due to their excellent sensitivity, extremely low detection limits, good accuracy and precision, as well as low cost of instrumentation. The Ads V technique is based on the accumulation of the analyte on a suitable working electrode by potential controlled adsorption and subsequent electrochemical oxidation or reduction of the preconcentrated species (Krolicka et al., 2003; Menek and Karaman, 2006b; Topçu 2016). With the voltammetric catalytic effect, the analysis of low concentrations of substances can be easily done by increasing the reduction peaks with suitable catalysts (Bobrowski and Zarebski, 2000; Jain et al., 1981; Barek et al., 1985; Uzun et al., 2014; Menek et al., 2014, Menek et al., 2001). In this study, the cobalt AR-27 complex was determined by voltammetry and it was aimed to increase the amount of current by catalytic effect of nitrite on this complex. Mercury electrode and graphite electrode, which are of great importance in voltammetry, were used for this purpose. With the help of the data obtained, the electrode mechanism was proposed.

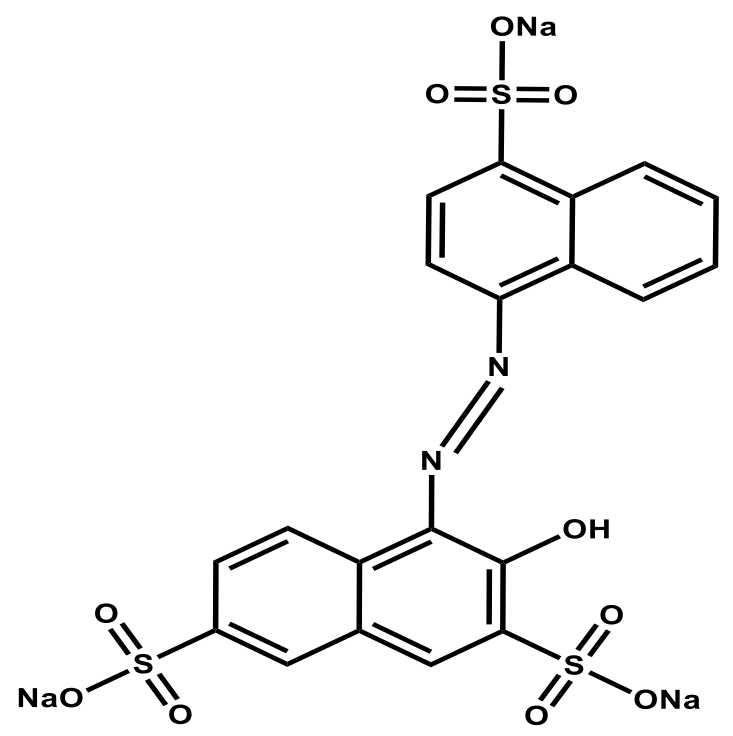

Figure.1 Acid Red 27

\section{Materials and Methods}

Acid Red 27 was obtained from Aldrich, $\mathrm{Co}\left(\mathrm{NO}_{3}\right)_{2} \cdot 6 \mathrm{H}_{2} \mathrm{O}$ is obtained from Merck 
company. $10 \mathrm{ml}$ 0.5 M Potassium nitrate media was preferred as the supporting electrolyte. The deionized water used in the preparation of the solutions was obtained from the Sartorius Arium model ultrapure water system. Voltammetric measurements were performed at room temperature by using Metrohm 757 VA Computrace Electrochemical Analyser. The device consists of $\mathrm{Ag} / \mathrm{AgCl}$ reference, $\mathrm{Pt}$ auxiliary and working electrodes. Hanging mercury Drop Electrode (HMDE) and Pencil Graphite Electrode (PGE) were preferred as working electrodes. $0.7 \mathrm{~mm}$ tombow brand pencil was used. Measurements were performed by dipping the pencil $1 \mathrm{~cm}$ into the voltammetric cell, and a new pencil was used for each measurement. Before each measurement, nitrogen gas was passed through the solutions for 5 minutes to remove oxygen. The study was conducted using the adsorptive square wave voltammetry (AdsSWV) technique.

\section{Research Findings}

\subsection{The behavior of Acid Red 27 and cobalt on HMDE and PGE}

Voltammetric behavior of AR-27 and $\mathrm{Co}^{2+}$ ions on HMDE and PGE were investigated in $10 \mathrm{ml}$ potassium nitrate media used as supporting electrolyte. Voltammograms formed by gradual addition of AR-27 to potassium nitrate medium are given in Figure 2. In the wide potential range $(0.0 \mathrm{~V})-(-1.2$ $\mathrm{V})$, only one reduction peak was found in the solution medium. The use of HMDE and PGE electrode has not changed the result. Considering the molecular structure of AR27 azo dyestuff (Figure 1.), this reduction peak arises due to the reduction of the electroactive azo group. In addition, the voltammetric peak current increases with the increase of the AR-27 concentration.
Voltammetric measurements performed at concentration levels of $10^{-5} \mathrm{M}, 10^{-4} \mathrm{M}$ respectively on HMDE and PGE are shown in Figure 2. These measurements were taken in the cathodic region by the adsorptive SWV method.
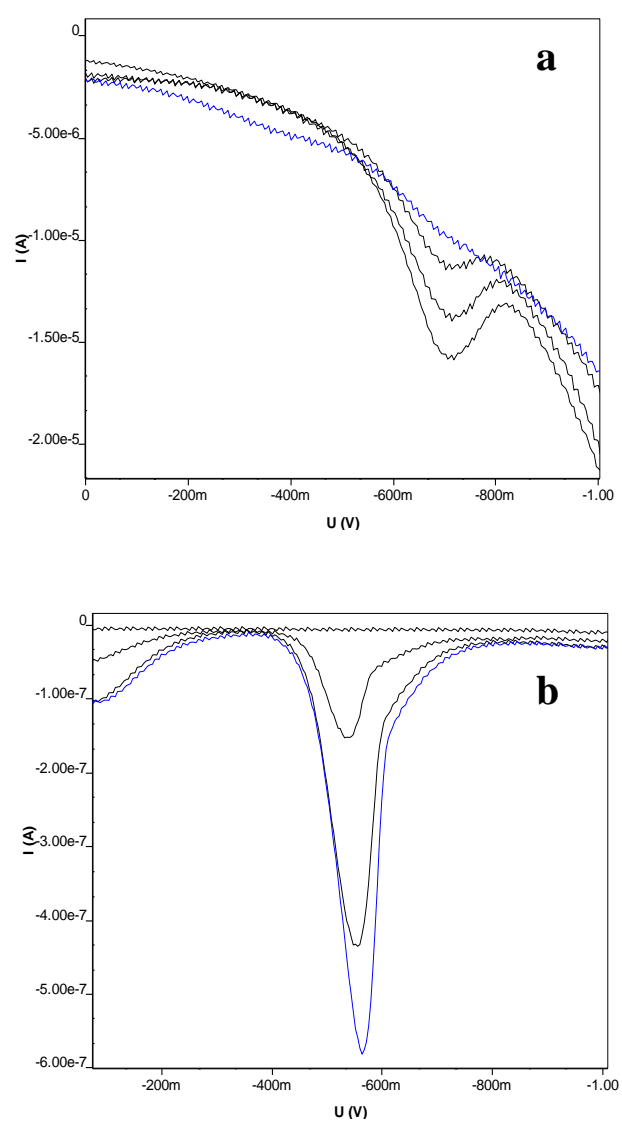

Figure 2. AdsSWV voltamograms of a) a series $10^{-4} \mathrm{M}$ AR -27 addition in $5 \mathrm{~s}$ deposition at -0.4 $\mathrm{V}$ on PGE b) a series $10^{-5} \mathrm{M}$ AR - 27 addition in $15 \mathrm{~s}$ deposition at $-0.4 \mathrm{~V}$ on HMDE in Potassium Nitrate Media

After examining the reduction signal of AR27, the behavior of $\mathrm{Co}^{2+}$ ion on PGE and HMDE was studied with voltammetry. The AdsSWV voltammograms of $\mathrm{Co}^{2+}$ ion at different accumulation potentials and different accumulation times were examined and the signals are given in Figure 3. As can be seen in Figure 3, although no reduction signal was found in PGE, the reduction peak of cobalt appeared on HMDE. 

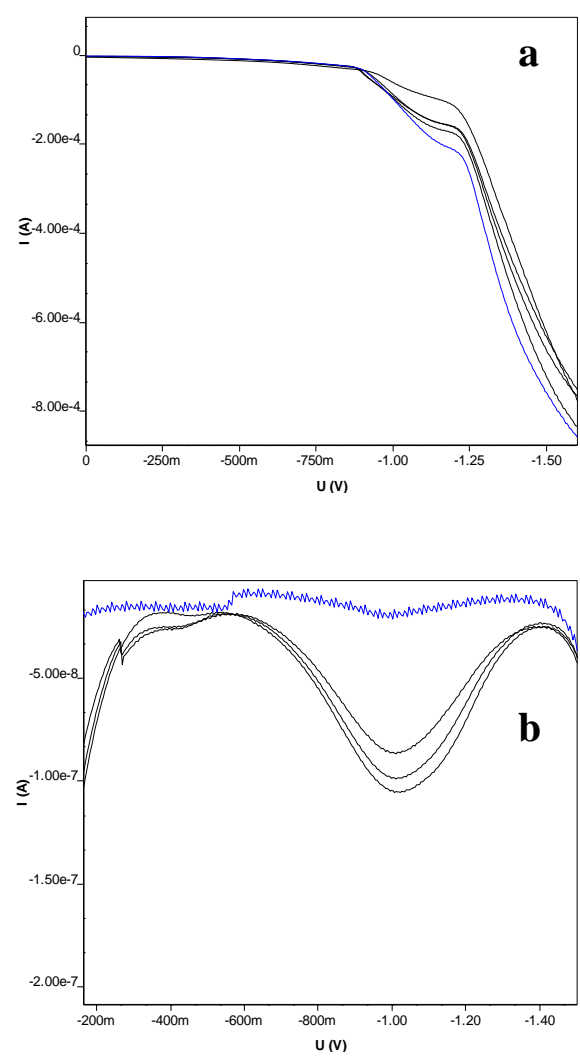

Figure 3. AdsSWV voltamograms of a) a series $10^{-4} \mathrm{M} \mathrm{Co}^{2+}$ addition in $5 \mathrm{~s}$ deposition at $-0.4 \mathrm{~V}$ on PGE b) a series $10^{-5} \mathrm{M} \mathrm{Co}^{2+}$ addition in $15 \mathrm{~s}$ deposition at $-0.4 \mathrm{~V}$ on HMDE in Potassium Nitrate Media

The interaction between $\mathrm{AR}-27$ and $\mathrm{Co}^{2+}$ ion and the complex structure that can form between them were studied by the AdsSWV technique (figure 4.). For this purpose, a series of $10^{-4} \mathrm{M} \mathrm{Co}^{2+}$ ions $\left(2 \times 10^{-4}, 4 \times 10^{-4}\right.$, $\left.6 \times 10^{-4} \mathrm{M}\right)$ were added in $6 \times 10^{-4} \mathrm{M}$ AR-27 in potassium nitrate media on PGE and a series of $10^{-5} \mathrm{M} \mathrm{Co}^{2+}\left(2 \times 10^{-5}, 4 \times 10^{-5}, 6 \times 10^{-5} \mathrm{M}\right)$ ions were added in $6 \times 10^{-4} \mathrm{M}$ AR-27 in potassium nitrate media on HMDE and the resulting voltammograms are given in Figure 4. When Figure 4 is examined, it is seen that if AR-27 is present in potassium nitrate medium, the reduction peak current increases upon addition of cobalt ion.
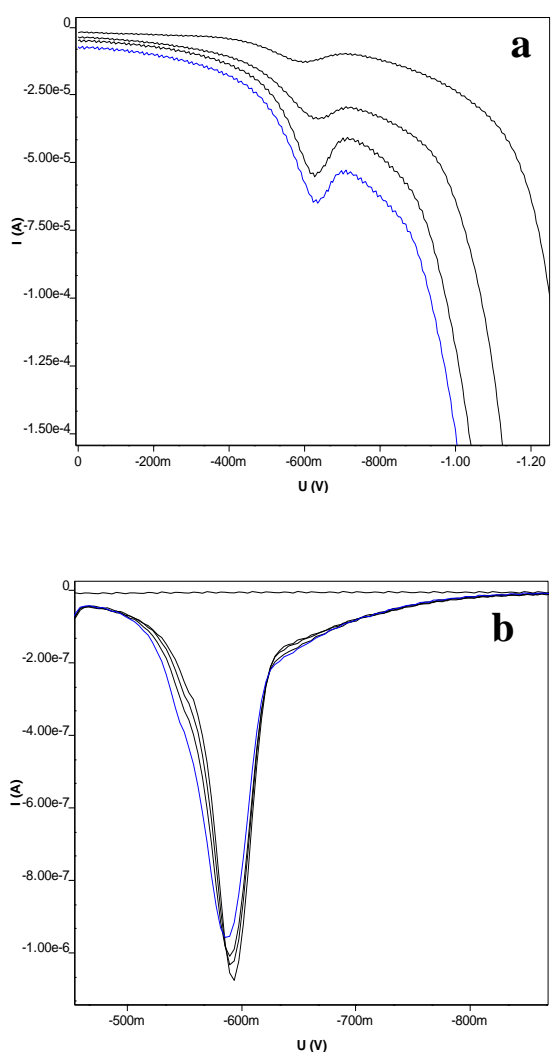

Figure 4. AdsSWV Voltammograms of a series of addition of $\mathrm{Co}^{2+}$ ions into AR-27 in Potassium Nitrate media a) -0.4 V $5 \mathrm{~s}$ deposition on PGE for $6 \times 10^{-4} \mathrm{M}$ AR-27 b) $-0.4 \mathrm{~V} 15 \mathrm{~s}$ deposition on HMDE for $6 \times 10^{-5} \mathrm{M}$ AR-27

\subsection{Determination of the optimum deposition potential for Acid Red 27-cobalt complex}

In Section 3.1, it was seen that AR-27 and cobalt ion formed a complex by the AdsSWV technique. There are many variable parameters in adsorptive techniques. One of these parameters is the accumulation potential. In order to determine the optimum accumulation potential, accumulation was performed in the range of $(-0.4 \mathrm{~V})-(0.0 \mathrm{~V})$ potentials with 5 seconds in PGE and 15 seconds in HMDE in potassium nitrate media with $6 \times 10^{-4} \mathrm{M} \mathrm{AR-27}$ and cobalt ion. The highest reduction peak current was observed to be at $-0.4 \mathrm{~V}$ (Figures 5 and 6). 

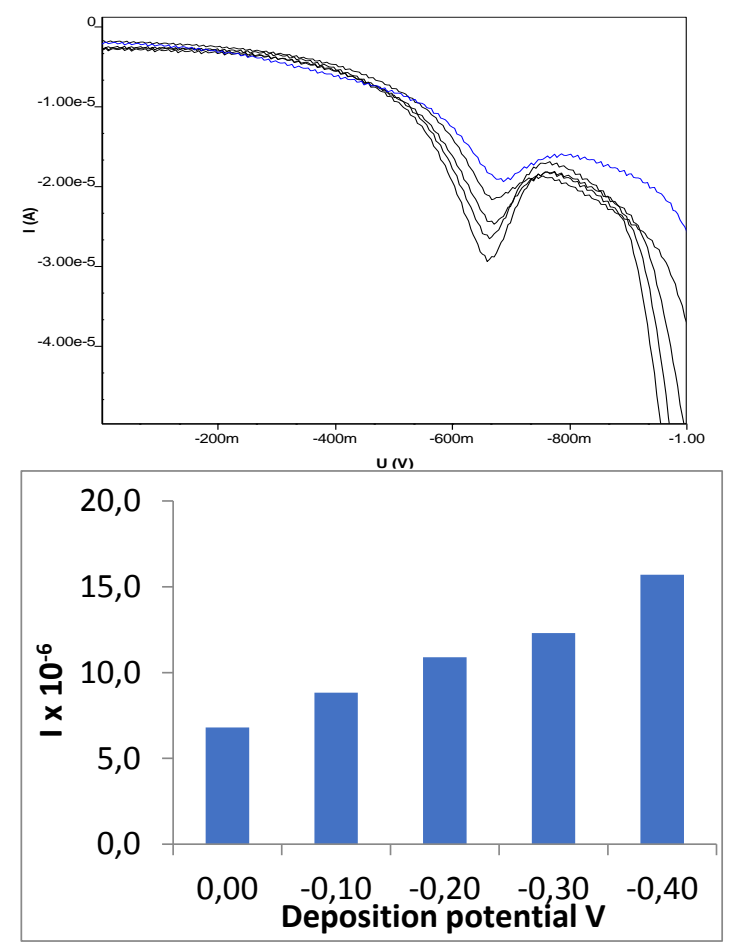

Figure 5. AdsSWV Voltammograms and current values of $6 \times 10^{-4} \mathrm{M}$ AR-27 and cobalt with $5 \mathrm{~s}$ accumulation on $\mathrm{PGE}$ in the range of deposition potentials
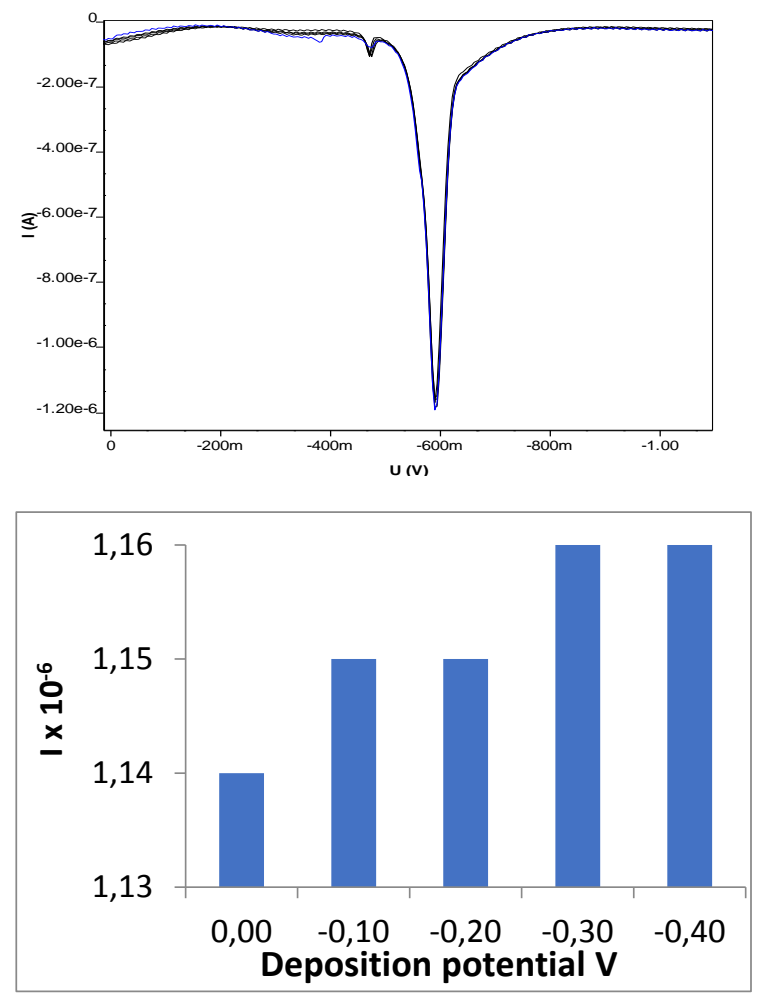

Figure 6. AdsSWV voltammograms and current values of $6 \times 10^{-5} \mathrm{M}$ AR-27 and cobalt with $5 \mathrm{~s}$ accumulation on HMDE in the range of deposition potentials

\subsection{Determination of the optimum deposition time for Acid Red 27-cobalt complex}

In Chapter 3.2, the optimum accumulation potential of $-0.4 \mathrm{~V}$ was selected for the determination of AR-27 and cobalt complex by AdsSWV technique. In order to determine the optimum deposition time, the deposition was performed by AdsSWV technique in a potassium nitrate media containing AR-27 and cobalt ion between 020 seconds on PGE and 0-120 seconds on HMDE. Voltammograms and current values of these changes are given in Figures 7 and 8.
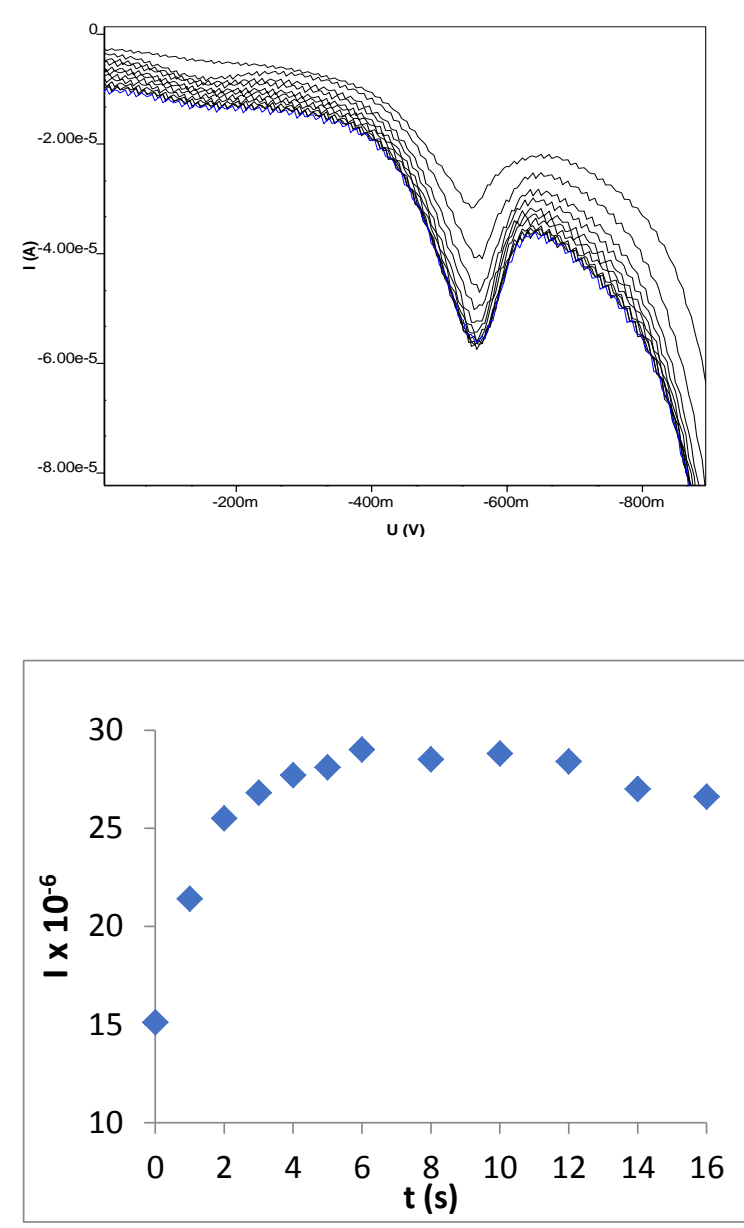

Figure 7. AdsSWV voltamograms and current values of $6 \times 10^{-4} \mathrm{M}$ AR-27 and cobalt in potassium nitrate media at $-0.4 \mathrm{~V}$ potential and different deposition times on PGE 

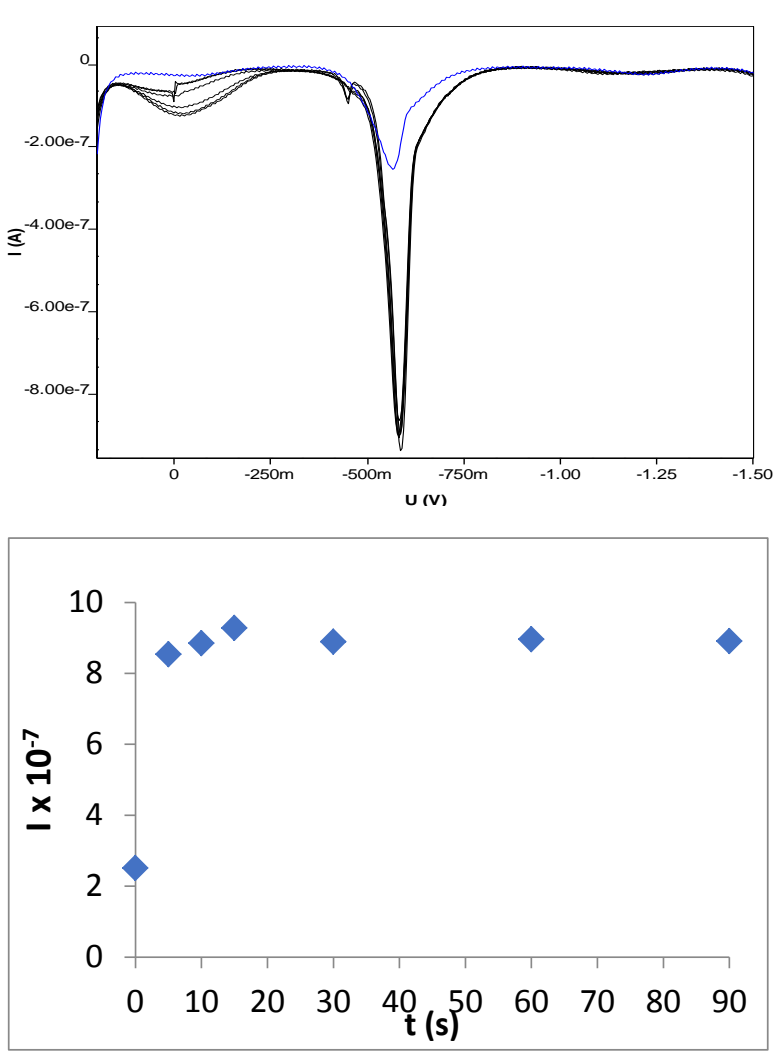

Figure 8. AdsSWV voltamograms and current values of $6 \times 10^{-5} \mathrm{M}$ AR-27 and cobalt in potassium nitrate media at $-0.4 \mathrm{~V}$ potential and different deposition times on HMDE

Deposition was performed on PGE and HMDE electrodes at $-0.4 \mathrm{~V}$ potential in the medium with Acid Red 27 and cobalt at different accumulation times and voltammograms and current values of these changes are given in Figures 7 and 8 . According to these changes, the current increases with the increment of the deposition time up to 6 seconds in the deposition process in the $0-20 \mathrm{~s}$ interval on PGE and, the current value remains constant despite the deposition time increases after 6 seconds. The current increases until $15 \mathrm{~s}$ accumulation and after 15 seconds the current value is fixed for HMDE. As a result, the optimum accumulation time was determined as $5 \mathrm{~s}$ for PGE and $15 \mathrm{~s}$ for HMDE.

\subsection{Optimum nitrite concentration for catalytic effect on Acid Red 27-cobalt complex}

In order to observe the optimum catalytic effect on the cobalt-AR-27 complex, a series of $5 \mathrm{M}$ nitrite were added to voltammetric cell Acid Red 27 in the potassium nitrate support electrolyte medium and $5 \mathrm{M}$ nitrite on the cobalt ion were added to a series of voltammetric cells which consist of CobaltAr-27 complex in nitrate media. The deposition processes were performed at -0.4 $\mathrm{V}$ for 5 seconds for PGE and $-0.4 \mathrm{~V}$ for 15 seconds for HMDE which were selected as the optimum condition in the previous sections. Voltamograms and \% current values of the resulting changes are given in Figures 9 and 10 respectively.
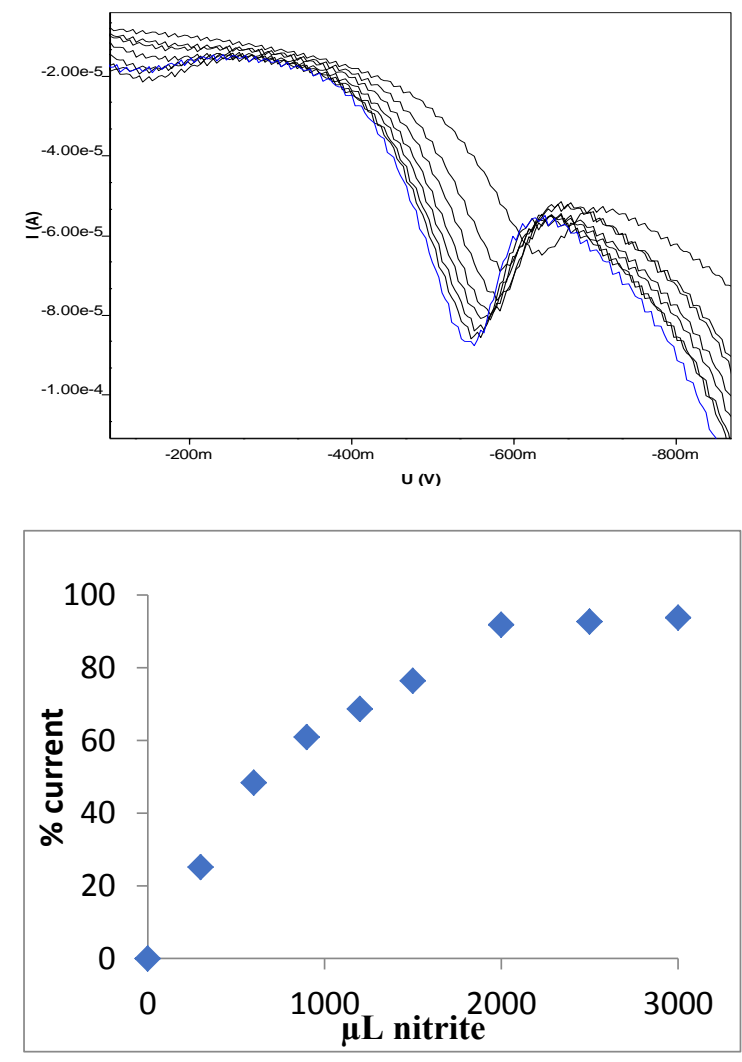

Figure 9. AdsSWV voltamograms and current \% values for nitrite addition into $6 \times 10^{-4} \mathrm{M}$ AR-27 and cobalt in potassium nitrate media at $-0.4 \mathrm{~V} 5$ $s$ deposition on PGE 

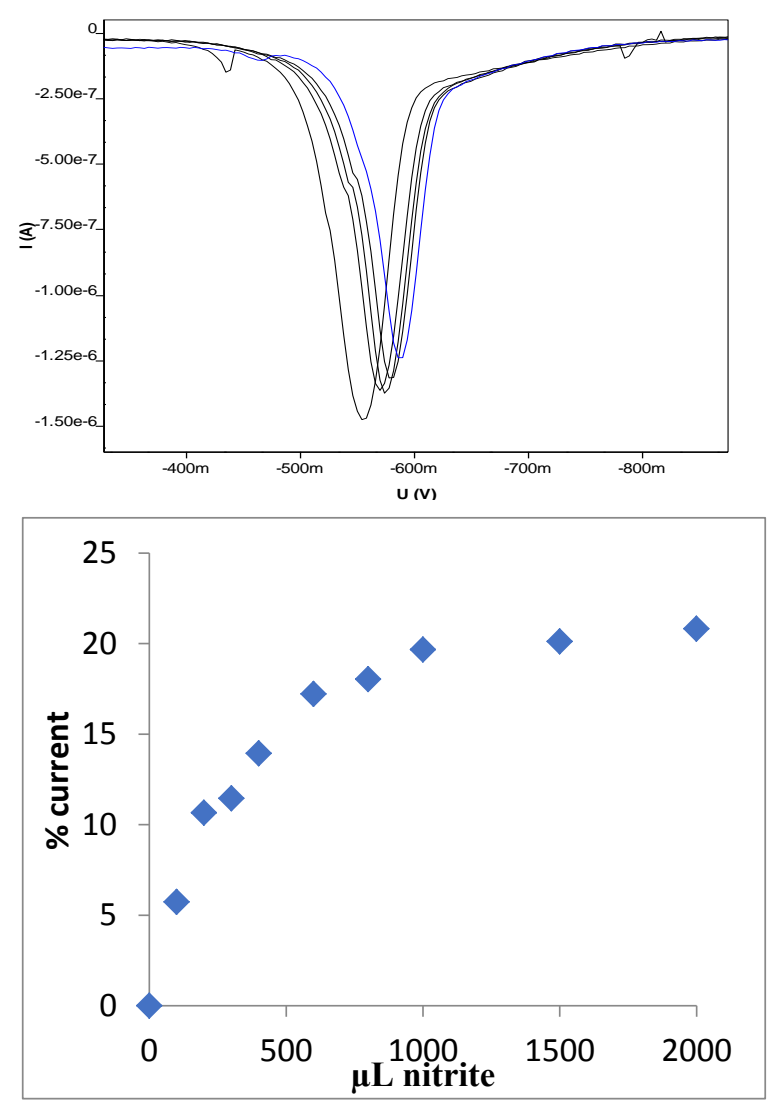

Figure 10. AdsSWV voltamograms and current $\%$ values for nitrite addition into $6 \times 10^{-5} \mathrm{M}$ AR-27 and cobalt in potassium nitrate media at $-0.4 \mathrm{~V} 5$ $s$ deposition on HMDE

\section{Results}

In this study, the catalytic effect of nitrite on cobalt-AR-27 complex formation in potassium nitrate medium was investigated by voltammety on PGE and HMDE. For this purpose, the current and potential of the complex were investigated in first step. When metal ions in the solution phase are complexed with ligands other than water molecules, their reduction waves change in two different ways. First, the reduction potential almost always shifts to more negative potentials. Second, its current changes and usually decreases (Crow, 1969). The complexation of ligands with metal ions in the solution media has two effects: a negative shift in the potential of the reduction wave and a significant decrease in the diffusion coefficient (Nepomnyashchii et al,
2008). Reduction signals of complexes can occur at a potential independent of the reduction signal of metal and dyes, and sometimes very close to the reduction potential of the dye or at the same place. Voltammetric studies also include determination of shifts in currents or halfwave potentials of metal ions in the presence of increasing amounts of complexing ligand (Crow, 1969). In this study, the reduction signal of the complex Acid Red 27 was very close to the reduction potential and shifts in the peak potential were observed. Although the cobalt ion did not give a reduction signal that could be evaluated analytically in the graphite pencil electrode, when $\mathrm{Co}^{2+}$ was added to the potassium nitrate media with AR-27, the signal increased in a region close to the reduction potential of AR-27. As can be seen in Figure 2, when cobalt ion is added to the nitrate media in the presence AR-27, the peak current increases and the peak current becomes more pronounced (Khatri and Singh, 1981; Nezhadali and Sharifi, 2010).

In this way, cobalt ions that do not signal alone on PGE emerge by signaling in the presence of AR-27. This phenomena provides an opportunity for indirect determination of cobalt ions in PGE. After determining the cobalt-AR-27 complex, optimal voltammetric parameters were defined for PGE and HMDE. In order to determine the optimum deposition potential, accumulations were performed in the range $(0.0 \mathrm{~V})-(-0.4 \mathrm{~V})$, and the optimum deposition potential $-0.4 \mathrm{~V}$ was selected for both PGE and HMDE. Another parameter that needs to be examined in adsorptive techniques is the deposition time. In voltammetry, a difference in the reduction current is observed depending on the deposition time. 


$$
\begin{aligned}
& \mathrm{Co}(\mathrm{II})+\mathrm{x}\left(\mathrm{Ar}{ }^{\prime}-\mathrm{N}=\mathrm{N}-\mathrm{Ar}\right) \longrightarrow \mathrm{Co}\left(\mathrm{Ar}^{\prime}-\mathrm{N}=\mathrm{N}-\mathrm{Ar}\right)_{\mathrm{x}} \\
& \mathrm{Co}\left(\mathrm{Ar}{ }^{\prime}-\mathrm{N}=\mathrm{N}-\mathrm{Ar}\right)_{\mathrm{x}(\text { solution })} \longrightarrow \mathrm{Co}\left(\mathrm{Ar}^{\prime}-\mathrm{N}=\mathrm{N}-\mathrm{Ar}\right)_{\mathrm{x}(\mathrm{ads})} \\
& \mathrm{Co}\left(\mathrm{Ar}^{\prime}-\mathrm{N}=\mathrm{N}-\mathrm{Ar}\right)_{\mathrm{ads}}+2 \mathrm{e}^{-}+2 \mathrm{H}^{+} \longrightarrow \mathrm{Co}\left(\mathrm{Ar}^{\prime}-\mathrm{HN}-\mathrm{NH}-\mathrm{Ar}\right)_{\mathrm{ads}}
\end{aligned}
$$

\section{$\uparrow$ \\ $\mathrm{Co}\left(\mathrm{Ar}{ }^{\prime}-\mathrm{HN}-\mathrm{NH}-\mathrm{Ar}\right)_{\mathrm{ads}}+2 \mathrm{NO}_{2}^{-}+2 \mathrm{H}^{+} \longrightarrow \mathrm{Co}\left(\mathrm{Ar}{ }^{\prime}-\mathrm{N}=\mathrm{N}-\mathrm{Ar}\right)_{\mathrm{ads}}+2 \mathrm{NO}+2 \mathrm{H}_{2} \mathrm{O}$}

Figure 11. Electrode mechanism of catalytic effect of nitrite on cobalt-AR-27 complex

\section{References}

Depending on the deposition time, the amount of material that can be reduced on the electrode surface is different, so there are variations in the amount of current accordingly. In addition, desorption can be observed with increasing deposition times (Bobrowski and Zarebski, 2000). However, after accumulating on the PGE in the range of $0-20 \mathrm{~s}$ at the potential of $-0.4 \mathrm{~V}$ deposition was performed and it was decided that the optimum deposition time was 5 s. After the optimum deposition times are selected, the electrode surface is saturated and the current value is fixed (Figures 7 and 8.). The optimum deposition time for HMDE is determined as $15 \mathrm{~s}$. As a result, nitrite catalytically increases the voltammetric peak current of the cobalt-AR-27. This phenomenon provides convenience for analysis at lower concentrations. A reaction mechanism is proposed that depends on the data obtained in Figure 11 and is compatible with the literature (Zhao et al., 1991).

\section{Acknowledgements:}

I thank the Giresun University Scientific Research Commission (FEN-BAP-A230218-20) for financial support.
Barek, J., Berka, A., ve Zima, J., 1985. "Determination of carcinogenic azobenzene derivatives by constant-potential coulometry", Collect. Czech. Chem. Commun., 50, 1819-1827.

Bobrowski, A., Zarebski, J., 2000. "Catalytic systems in adsorptive stripping voltammetry", Electroanalysis, 12, 11771186.

Crow, D.R. 1969. "Polarography of Metal Complexes", Academic Press, 56-57, London

Griffith, J., 1976. "Colour and Constitution of Organic Molecules", Academic Press, London

Hart, J.P., Smyth, W.F., 1980. "Polarographic Behaviour and Analysis of Some Azo Dyes of Biological Significance", The Analyst, 105, 929-938.

Jain, R., Rani, S., Goyal, R.N., 1981. "Polarographic behaviour of some potential antidiabetic

benzylsulphonylarylazopyrazoles", Electochim. Acta, 26(11), 1519-1523.

Karaman, Y. Uçar, M., Menek, N., 2018. "Polarographic and Voltammetric Investigation of Sudan I", Chemical Science International Journal, 25,1, 1-12. 
Karaman Y., Menek N., Biçer, F., A., Ölmez, H., 2015. "Voltammetric Investigations of 2,2'-Azobispyridine Zinc(II) and Nickel(II) Complexes", International Journal of Electrochemical Science, 10, 3106 - 3116

Karaman, Y. 2014. "Investigation of electrochemical behaviour of Calmagite at a glassy carbon electrode", Dyes and Pigments, 106, 39-44.

Karaman Y., Menek N., 2012. "Investigation of Electrochemical Behavior of 2-(5-Bromo2-Pyridylazo)-5-[N-Propyl-N-(3-

Sulfopropyl)Amino] Phenol Disodium Salt Dihydrate", Journal of the Electrochemical Society, 159, 805-810.

Khatri, J. ve Singh, M. 1981. "Polarographic Study of L-Tryptophan Complexes of Zn (II), Ni (II) \& Co (II) ", Indian J. Chem, 20A, 1144-1145.

Krolicka, A., Bobrowski, A., Kalcher, K., Mocak, J., Svancara, I., Vytras, K., 2003. "Study on Catalytic Adsorptive Stripping Voltammetry of Trace Cobalt at Bismuth Film Electrodes", Electroanalysis, 15, 18591863.

Menek, N., Başaran, S., Karaman, Y., Topçu, S., 2013. "Investigation of electrochemical behaviour of 3- allyl-4-hydroxy-3'-4' dimethylazobenzene", Int. J. Electrochem. Sci., 8, 6399-6407.

Menek, N., Eren, E., Topçu, S., 2006a. "Kinetic investigation of an azo dye oxidation by hydrogen peroxide in aqueous surfactant solution", Dyes and Pigments, 68, 2, 205-210.

Menek, N., Karaman, Y., 2006b. "Polarographic and voltammetric investigation of 6'-butoxy-2,6-diamino-3,3'azodipyridine", Dyes and Pigments, 68,2,101-108.

Menek, N., Karaman, Y., 2005. "Polarographic and voltammetric investigation of 8-hydroxy-7-(4-sulfo-1naphthylazo)-5-quinoline sulfonic acid", Dyes and Pigments, 67, 9-14.
Menek, N., Topçu, S., 2003. "Electrochemical behaviour of 5-Methyl-(2Thiazolylazo)-Resorcinol", Bulletin of Electrochemistry, 19(3), 133-137.

Menek, N., Topçu, S., Uçar, M. 2001. "Voltammetric and spectrophotometric studies of 2-(5-bromo-2-pyridylazo)5diethylamino)phenol copper(II) complex" Analytical Letters, 34, 10, 1733-1740.

Topçu, S. 2016. "Electrochemical and Theoretical Studies of Some Aromatic Oxime Derivatives Carrying- $\mathrm{C}=\mathrm{O}$ and $-\mathrm{NH}-$ $\mathrm{R}^{\prime}$ Groups in the $\alpha$-Position' Journal of The Electrochemical Society", 163, 9, 122-126.

Uzun, I.,Güler, B., Uçarlı, O., Bodrumlu, E., Menek, N., 2014. "Assessment of the Nickel Ion Releases from the Broken Stainless Steel and Nickel Titanium Endodontic Instruments" International Journal of Electrochemical Science, 9, 5812-5819.

Menek, N., Uçarlı, O., Zeyrekli, S., Topçu, S., Karaman, Y. 2014., "Investigation of Catalytic Effect Nitrite on Electrochemical Reduction of Cobalt imethylglyoxime Complex by Polarographic and Voltammetric Techniques", International Journal of Electrochemical Science, 9, 2445-2453.

Murty Srinivas D., Patel Suhagi D., Soni Rakesh and Bhatt Nikhil 2012. "Isolation and Identification of Bacterial Culture for Azo Dye Degrading Capability", International Journal of Research in Chemistry and Environment, 2, 4, 69-79.

Nepomnyashchii, A. B., Alpuche-Aviles, M. A., Pan, S., Zhan, D., Fan, F.-R. F. ve Bard, A. J. 2008. "Cyclic voltammetry studies of $\mathrm{Cd}^{2+}$ and $\mathrm{Zn}^{2+}$ complexation with hydroxylterminated polyamidoamine generation 2 dendrimer at a mercury microelectrode", Journal of Electroanalytical Chemistry, 621:2, 286-296.

Nezhadali, A. ve Sharifi, H. 2010. "Study of complex formation constants for some cations with O-Phenylenediamine in binary systems using square wave polarography technique", Engineering, 2:12, 1026. 
Patai, S., 1975. "The Chemistry of the Hydrazo, Azo and Azoxy Groups",Vol. 1, John Wiley\&Sons, 597p, London.

Strandis, J., Glezer, V., 1979. "Encylopedia of the Electrochemistry of the Elements", Vol. 13, (Editor: A.J. Bard, H. Lund) Dekker, 163-209, New York.

Zhao, Z., Cai, X., Pei, J., Zhang, Y., Zhou, $X ., 1991$. "Studies on the electrochemical behaviour of 2-(3,5-dibromo-2-pyridyl)azo5-diethylaminophenol-Co(II) complex in the presence of nitrite: trace measurements of cobalt", Electroanalysis, 3,949-954. 